The role of research orientation for attracting competitive research funding

Hanna Hottenrott

DEPARTMENT OF MANAGERIAL ECONOMICS, STRATEGY AND INNOVATION (MSI) 


\title{
The Role of Research Orientation for Attracting Competitive Research Funding*
}

\author{
Hanna Hottenrott ${ }^{\mathrm{a}, \mathrm{b}}$ \\ ${ }^{a}$ K.U.Leuven, Dept. of Managerial Economics, Strategy and Innovation \\ ${ }^{d}$ Centre for European Economic Research (ZEW), Mannheim
}

March 2011

\begin{abstract}
This article studies the role of research orientation for attracting research grants at higher education institutions in Germany. Traditionally research activities were funded by the institutions' core budget. More recently, extramural research funding has become increasingly important. Besides the public sector, industry provides a growing share of such funds. The results based on a sample of professors in science and engineering suggest that basic and applied research is complementarity for attracting research funding from industry. Thus, professors who conduct basic research in addition to research on the applicability of their results appear to be a more interesting target or most successful in raising industry funds. For raising grants from public sources, it turns out that specialization is more important. Specialized research units on either basic or applied research obtain significantly more public grants which points to a substitutive relationship between basic and applied research for grants from public sources.
\end{abstract}

Keywords: $\quad$ Applied Research, Basic Research, Research Funding, UniversityIndustry Technology Transfer

JEL-Classification: $\mathrm{O} 31, \mathrm{O} 32, \mathrm{O} 33$

Address: Hanna Hottenrott, K.U.Leuven, Dept. of Managerial Economics, Strategy and Innovation Naamsestraat69,3000 Leuven, Belgium, hanna.hottenrott@econ.kuleuven.be

\footnotetext{
* The author is grateful to the Centre for European Economic Research (ZEW) for providing the survey data, to Thorsten Doherr for help in retrieving the patent data, to Susanne Thorwarth for help in data preparation, and to the Flemish Science Foundation (FWO) for financial support.
} 


\section{INTRODUCTION}

Following the idea that university systems with competitive funding mechanisms provide output incentives and are consequently more efficient and more productive than traditional funding environments, university research in Europe is increasingly funded by a mix of 'fixed' institutional budget and project-based funds (Auranen and Nieminen 2010). The latter can be raised from diverse sources. Public funding schemes from regional, national or supranational sources including governments as well as research foundations and to an increasing extent industrial grants and contracts provide such extramural funds.

Besides this shift in the universities' funding environments, technological change increasingly depends on academic research (Nelson 1986, von Hippel 1988, Jaffe 1989, Mansfield 1991, Acs et al. 1992). In particular the growth of "science-based technologies" such as biotechnology, information technologies, and sophisticated materials, strengthened the relevance of science for technological innovation. The role of universities has therefore been seen in facilitating the translation of basic science into applicable technology. The extent to which a university contributes to innovation in a particular industry depends (at least in part) on the industrial support for research at that university (Mansfield 1995). Although industry funding accounts only for a relatively small share of the overall research expenditures in most OECD countries, it still receives considerable attention. The possibility for researchers to raise funds from private sector firms may open-up new opportunities for researchers and such funds may constitute a basis on which science and industry interact and thereby create social and economic returns (Mansfield 1995, Hall et al. 2003).

While previous literature found academic research to be highly valuable for industrial innovation (Mansfield 1998; Narin et al. 1997; Zucker et al. 2002; Hall et al. 2001a; Cassiman et al 2008), the criteria and qualities according to which firms approach academics has not been studied as extensively. Do firms benefit from sourcing basic science that is not feasible or unprofitable to built-up themselves? Or do they seek access to rather applied research that provides knowledge that is closer to applicable technology and thus closer to marketable innovations? The main underlying question is thus whether firms substitute or complement their own R\&D with university research. Another question that arises is whether research orientation plays a different role for the successful acquisition of public grants as compared to industry funds. The rationale behind public research funding has traditionally been based on the positive externalities from basic science. Public funding for applied research, on the other hand, usually has been linked to public-private research partnerships and has been justified by 
the resulting wider economic benefits from such collaboration. Given the limits of public funds, award criteria generally revolve around academic excellence (Viner et al. 2004, Sorensen and Fleming 2004) which, in turn, is reflected in the research focus of awardees. Excellence may require a high degree of specialization which facilitates the creation of an accumulative advantage.

This article adds to previous research by studying the role of research orientation, i.e. basic versus applied research, for attracting competitive research funding from the private as well as from the public sector. The sample of 678 research units at 48 higher education institutions in Germany covers a broad range of disciplines from science and engineering. The results suggest that basic and applied research is complementary for raising funds from industry. Professors whose labs conduct both types of research attract most funding from industry in contrast to those who are focused on either basic or applied research, both in monetary terms as well as in percent of their total research budget. For raising grants from public sources, on the other hand, specialization seems more important. Specialized research units on either basic or applied research obtain significantly more public grants pointing to a substitutive relationship between basic and applied research for such grants.

The article proceeds as follows. Section 2 gives an overview of insights from previous research; section 3 describes the data and sets out the empirical framework. Section 4 presents the results. Section 5 briefly discusses some robustness checks before section 6 concludes and points out roads for further research.

\section{BASIC RESEARCH, APPLIED RESEARCH, OR BEST BOTH?}

While research activities were traditionally funded by the institutions' core funding, more recently additional grants make up an ever larger share of universities research budgets (Schmoch and Schubert 2009, Auranen and Nieminen 2010). Besides the growing role of funding from the private business sector, public research funding is also becoming increasingly competitive. The rules and precepts according to which such funds are granted may naturally differ between schemes and sponsors.

Most research in the field of industry-science linkages takes the viewpoint of the firm. That is which firms collaborate with universities, and what benefits emerge for these firms (Gambardella 1992, Cassiman et al. 2008, 2010). Acquisition of scientific research has been shown to be beneficial for firms in many respects ranging from increased productivity of their 
own R\&D efforts (Cockburn and Henderson 1998), to a reduction in labor cost (Stern 2004). It had also been argued that science provides information to industry about promising future technology development and thereby avoiding or reducing firms" "search costs" for ideas (Dasgupta and David 1994, Hall et al. 2003, Crespi et al. 2007). Thus, sourcing technological knowledge from universities moreover reduces firms' risk of expanding in new fields of technology (e.g. Mowery 1998; Zucker and Darby 1996; Zucker et al. 2002). Financing university research may constitute a channel through which industry seeks access to science directly and more specifically compared to scientific information that is open to the general public. As studies for instance by Zucker and Darby (1996) and Cockburn and Henderson (1998) have shown, industry scientists increasingly conduct research and publish results jointly with university researchers. These activities may be the outcome of sponsored research. Less evidence can be found on the characteristics of university researchers, departments and universities who are most successful in raising research funding from industry. The reason for this lack of attention in the literature so far could be found in the seemingly obviousness of the question who attracts industry funding. As argued by Trajtenberg et al. (1997) industry R\&D is directed at commercial success while university research focuses on solving fundamental science questions. Scientific research moreover relies on an in-debt discussion of previous research and involves careful documentation of trial and error in the research process. Industry research on the other hand is rather focused on exploitation of existing technologies and is not subject to rules of scientific research conduct (Fleming and Sorensen 2004).

This notion implies that universities represent a medium producing basic scientific knowledge that serves as basis for industrial innovation. Thus, it seems obvious to assume that firms fund university research to gain access to such basic research. that complements their own application-oriented R\&D. This is supported by Czarnitzki et al. (2009) who study the basicness of patents of German professors and find that these academic patents are opposed less frequently than a control group of corporate patents. They argue that this suggests that academic patents cover rather basic inventions with low immediate commercial value. For academic patents in collaboration with the business sector that may also be the outcome of sponsored research the effect turns out to be weaker, which suggests that those patents are evaluated as more applied by owners of potentially rival technologies. Jensen et al.'s (2010) results also suggest that university research projects are more basic than firm projects and that there are spillovers from university research to firms. Sourcing knowledge from universities 
directly via grants and contracts may thus be particular relevant for firms whose R\&D employees lack specific skills or resources to conduct basic research in-house or firms that want to reduce the risk and costs related to it. Veugelers and Cassiman (2005) find for their sample of firms located in Belgium that firms impeded by costs to innovate are more likely to cooperate with universities, hinting to a substitutive relationship between firm-level and university research.

However, firms cannot absorb scientific knowledge without efforts. Cockburn et al. (1999) study incentives for basic and applied research in the pharmaceutical industry that - in the late 1970s - was subject to significant changes in research directed at drug discovery. In particular, advances in university research in the fields of biochemistry and molecular biology resulted in "a new technology for drug discovery" in which success in applied research depended on the researchers' prior experience in related basic research (see also Toole 2007). Their study exemplifies how firms can react to the increasing importance of science-based technologies and hence the increasing relevance of university-generated knowledge for industry. Firms can either adapt in-house incentives for basic research or they can increase collaboration with university scientists directly such as by sponsoring research projects conducted within universities. In both cases investments in absorptive capacity may be crucial. The extent of such investment, however, may depend on whether they source solely basic research or whether they are able to contract researchers who have a less specialized research focus, i.e. that comprise both basic and applied research skills.

Thursby and Thursby (2004) suggest that absorptive capacity is moreover necessary for firms to monitor research efforts within sponsored research agreements. Consequently, it could be argued that applied science is easier to identify and to exploit for industry and involves lower monitoring costs. Hence, instead of sourcing pure basic research results firms could target university research that is more applied and consequently less costly to adopt. In other words, industry could be more willing to seek access to (technological) knowledge that is less basic, has passed a certain threshold of applicability, and is thus closer to industry demands.

The role of research orientation for attracting third-party funding may thus not only be a crucial one, but also one that had been studied less thoroughly than for instance the effects of such grants on academic productivity (Jacob and Lefgren 2007, Hottenrott and Thorwarth 2010). One notable exception is an exploratory study by Gulbransen and Smeby (2005). Based on the claim that increased industrial funding will force universities into taking on ever more applied research (Geuna 2001; Geuna and Nesta 2006), they study differences in 
research orientation between university professors with industrial funding and professors with other types of funding or no external research funding. They find support in their Norwegian data for the hypothesis that professors with industrial funding indeed describe their research more often as applied than professors without industrial funding. Whether professors with an ex-ante applied research orientation are more likely to receive (more) funds from industry than others is beyond the scope of their analysis.

Previous studies did, however, shed some light on the question which fields of science particular industries were interested in and on the importance of geographical proximity for getting funded by industry as well as on faculty quality (Mansfield 1995, Mansfield and Lee 1996). At the university-level Ljungberg (2008) finds mainly larger and highly specialized universities in Sweden attract most industry funding relative to their size. The larger but less specialized universities and most of the smaller regional colleges and universities receive less. Thus, he sees specialization in research as important characteristic for explaining differences in the ability to attract firm funding. Broström (2011) finds in a study on firms collaborating with major Swedish universities that these firms work with university researchers in order to access academic networks and to strengthen skills of their employees, i.e. increasing absorptive capacity for knowledge spillovers in general, not only from science. This may suggest that firms are less interested in highly specialized research unit, but in those that provide a variety of skills.

Thursby and Thursby (2002) study businesses that license-in university technologies and find that such technologies are mostly early stage technologies, i.e. require further research on their application. They also show that if inventions are 'too embryonic to license', firms use the channel of sponsoring research to pursue the invention. They measure the firms' absorptive capacity by the portion of the firm's basic research share and argue that if university research is a substitute for firm $R \& D$, firms with higher absorptive capacity rely less on university research. Their results support the hypothesis that university and industry basic research are complementary and that firms also value applied university research in the development phase of a licensed university invention. These results are confirmed in a later study by Thursby et al. (2007) suggesting that the majority of inventions licensed are so 'embryonic' that for commercialization to be successful, faculty participation in further development is crucial. This implies that both basic research as well as research on the applicability of the results may be an important criterion for firms to direct their research sponsoring. Moreover, the possibility to attract research grants from industry may create 
incentives for researchers that usually have a taste for rather basic research to also focus their work on commercial development (Levin and Stephan 1991, Jensen and Thursby 2001, Jensen et al. 2003).

With respect to research orientation public grants may be granted on different means as compared to private sector funds. In many countries the share of direct, fixed public research funding has stagnated or even decreased over the past decades (Geuna and Nesta 2006), while the share of public funding that is being allocated based on "mission-oriented" or "contractbased strategic allocation procedures" has been rising (Viner et al. 2004, Auranen and Nieminen 2010). Regardless of the forms of funds' allocation, public funding constitutes the predominant source of funding for university research (OECD 2007, 2009, Bozeman and Gaughan 2007). Public research funding, in particular basic research, is usually justified on the grounds of the high social value it creates. There is indeed extensive evidence that basic research does also lead to considerable economic benefits (see Salter and Martin 2001 for a review). Thus, one would expect basic research to attract the majority of public grants.

However, as policies and funding programs have been initiated that particularly aim at fostering EU countries' economic strength in converting top-level scientific research output into marketable innovations, an increased attention of public funding authorities also on applied research could be expected. Besides a number of non-funding-related policies like Bayh-Dole Act type of legislations and the abolishment of the so-called professor privilege in several European countries among which Germany, Denmark and Austria that exempted university professors from the obligation to transfer intellectual property rights of their publicly funded inventions to their home institution (Von Ledebur et al. 2009), a trend in promoting industry-science collaboration can be observed. In Germany "direct project funding" by the Federal Government, for instance, has been to an increasing extent directed at promoting industry-science consortia, while grants given to pure firm research consortia or pure science consortia did not grow at comparable rates (Czarnitzki et al. 2008). Results from an interview-based study by Broström (2011) even suggest public co-funding of collaborative research between university and industry should be awarded on the merits of applicationoriented problem solving rather than fundamental research alone as it increases incentives in the business sector to participate in such programs. This claim, however, stands in stark contrast the rationale behind public funding of $R \& D$ that is usually based on the assertion that basic research is associated with positive spillover effects to the entire economy (see Feldman 
and Kelley 2006 for an overview). In the same line of reasoning, public funding of applied projects might be considered as inefficient and thus as undesired (Mowery 1998).

In any case, given the constraints in the availability of public funds, award criteria generally revolve around academic excellence (Viner et al. 2004, Sorensen and Fleming 2004). The evaluation of scientific excellence is mostly based on peer-review reports (Jacobs and Lefgren 2007). The strong focus on excellence may also be reflected in the research focus of awardees. Excellence may require a high degree of specialization which facilitates the creation of an accumulative advantage at the level of the individual researcher or the research team.

This study aims to contribute to the understanding of how university research matches industry demands for scientific knowledge by analyzing the role of research orientation for the attraction of competitive research funding. Given the previous discussion, we expect this role to differ between public and private sector sources. On the one hand firms may fund basic university research that complements their in-house applied research or to increase basic research skills of their own researchers. On the other, firms may source applied university research as they can absorb such knowledge input at lower cost and it reduces the 'distance' from basic science to applicable technology that may be especially large for early-stage technologies. As both arguments are straight forward, one could reason that firms prefer those researchers as collaboration partners - and hence as sponsoring targets - whose labs are capable of doing both basic as well as applied research. If that applies empirically, we would expect to find a complementary relationship between basic and applied research orientation.

Unlike for industry grants, the complementary argument is less suitable for public grants. Funding authorities do not face a trade-off between the benefits from accessing basic research and the costs of building absorptive capacities to fruitfully use such knowledge inputs. For public grants the most important objective should be to derive the highest returns to society from the amount spent. Thus, experts conducting ground-breaking basic research on the one hand, but also applied researchers who contribute with their work to the translation of science into day-to-day applicable technology, on the other, may be the desired targets.

Besides the effects of researchers' research focus, their academic achievements in terms of scientific publications as well as invention disclosures in the form of patent applications are in addition to lab and institution characteristics - taken into account for their willingness or ability to attract research grants from either source. 


\section{DATA AND EMPIRICAL FRAMEWORK}

The data for the following analysis had been collected from different data sources. First, a survey among research units at German higher education institutions (stratified by regions) in the fields of science or engineering has been conducted in 2000 by the Centre for European Economic Research (ZEW, Mannheim). The survey addressed "heads of research units" at different types of institutes: universities, technical universities and polytechnic colleges. Thus, the unit of analysis is the research lab. In the German system of higher education this typically means that one full professor heads a research unit with scientific assistants (preand post-doctorates) as well as non-scientific technical and administrative staff. The range of public research institutions in Germany comprises institutions that are committed to different fields of research (general universities vs. polytechnics and technical universities) and also to different technology transfer channels. The publicly funded R\&D infrastructure in Germany also includes non-university research (Beise and Stahl 1999). The original survey also addressed such public non-profit research institutions such as Fraunhofer or Max-Planck institutes. We excluded these responses from our analysis as these public non-profit research institutions differ substantially from research units at universities and polytechnics, for instance with respect to the fact that there is no teaching, no graduate education and the organizational structure is different from the three types of universities. ${ }^{1}$ This study thus focuses on scientists at general and technical universities as swell as at polytechnics who are also occupied with teaching. After the elimination of incomplete records the final sample contains 669 professor-research unit observations from 46 different institutions of which 56\% are universities, $23 \%$ are technical universities and $21 \%$ are polytechnics.

The main variables of interest are obtained directly from the survey. Professors indicated the percentage of their units' research that is directed at basic research (BASIC_SHARE) or applied research (APPLIED_SHARE). The original survey data distinguished applied research and experimental development. For the purpose of this study, the latter category had been added to the applied research share. As BASIC_SHARE and APPLIED_SHARE add up to 1, it is necessary to multiply the individual shares are with the number of scientific staff (mean $=13$, median $=$ 9 and the maximum number is 130). This transformation results in a slight shift in interpretation of the variable from 'share of effort devoted to basic or applied research' to

\footnotetext{
${ }^{1}$ See Czarnitzki and Rammer (2003) for more details on the institutional structures of higher education in Germany.
} 
'staff working on basic or applied research'. Thus, it ought to be kept in mind for the interpretation of the results that these variables (BASIC and APPLIED) also measure lab size.

Moreover, the amount of private-sector research grants, i.e. money from industrial firms received during 1999 both in monetary terms (INDFUND) as well as share of their overall budget (INDSHARE) and the corresponding information on public grants (GOVFUND, GOVSHARE) is obtained immediately from the survey. The sum of INDFUND and GOVFUND is 'total third-party funding'. Adding this to the 'core' institutional funding (COREFUND) yields the units' overall funding: TOTALFUND = INDFUND + GOVFUND + COREFUND.

General universities were traditionally known for teaching and basic research without directly aiming at commercialization of their research results. The main transfer channel thus is the publication of research results. The share of research grants from industry is thus lower compared to technical universities or polytechnics. However, the shares of public grants of total budgets are, on average, larger than for the other types of institutions (see Table A.2). In contrast, technical universities and polytechnics have a tradition of industry-related research. According to Beise and Stahl (1999) polytechnics are often specialized in the same technical fields as local businesses and are supposed to support small- and medium-sized firms through consultancy and the supply of graduates. Polytechnics usually focus on education, but do also conduct research that has a reputation for being "down-to-earth".

To control for other important determinants of research grants besides research orientation for both types of sources, a number of additional variables are included in the analysis. Most importantly, the previous scientific performance of the research unit's heads may also impact the attraction of grants (e.g. Murray 2002, Viner et al. 2004, Grimpe and Fier 2009). Thus, the survey data has been supplemented with publication and patent information. Past scientific publications of the professors have been collected from the ISI Web of Science ${ }^{\circledR}$ database using the ISI Web of Knowledge ${ }^{\circledR}$ platform. This information includes publications (articles, notes, reviews and letters) of professors in our sample (PUBS) as well as the number of citations these publications received (CIT_PUBS). We searched for publications by the professors' names and subsequently filtered results on the basis of affiliations, addresses and journal fields. Information on patent applications (PATS) on which the respective professor occurred as inventor is drawn from the data base of the German Patent and Trademark Office (DPMA). We searched for the professors' names in the inventor information in the patent file. To assess the quality or impact of the patents forward citations to these patents are collected as well (CIT_PATS). Patent forward citations have been shown to be a suitable measure for the 
quality, importance or significance of a patented invention and have been used in various studies (see e.g. Henderson et al. 1998; Hall et al. 2001b; Trajtenberg 2001 or Czarnitzki et al. 2008). As a third performance measure, the average number of citations per publication (patent) is calculated (CIT_per_PUB, CIT_per_PAT). For our main analysis we limit the time horizon ("activity window") for publications, counts of patents, and citations to both, to the period from 1994 to 1999.

As the effectiveness with which a research unit attracts third-party funding may among other factors depend on the head's experience or seniority, information from the German National Library on the year in which the professor received his $\mathrm{PhD}$ was gathered. ${ }^{2}$ From this information the years of the professors' experience (EXPER) in academe was calculated. To test for any non-linear life-cycle effect (Levin and Stephan 1991), the squared value (EXPER $\left.{ }^{2}\right)$ is included as well. Although all professors in the sample are rather senior academic staff represented in the fact that they are heading a research unit, it may still be adequate to control for differences in seniority.

For differences in the size of the different institutions is controlled by including the (logged) total number of students $\ln (U N I$ SIZE $)$. Larger universities may, for instance, be more visible to funding agencies and to industry and thus attract relatively more third-party funding. A squared term is included to control for non-linearity in UNI_SIZE. Moreover, it is known from the survey whether the professor had contact to his institution's Technology Transfer Office (TTO). As it is conceivable that such contacts impact both stronger technology transfer awareness and the likelihood of establishing contracts with industry, it may also affect industry funding. We control for differences between research fields by including seven field dummies (see Table A.2 for key variables by research field). Three institution type dummies are added to capture differences in funding patterns due to the type of institution (university, technical university and polytechnic). Finally, we include a gender dummy (FEMALE). Table 1 shows descriptive statistics of the main variables of interest.

Research units in the sample obtained about 96.5 thousand Euros from industry on average. This makes up for $8.6 \%$ of the total budget in 1999. Grants from public sources amounted to

\footnotetext{
2 In Germany a dissertation needs to be published in the German National Library (Deutsche Nationalbibliothek). This central archival library among other things, collects, permanently archives, comprehensively documents and records bibliographically all German and German-language publications from 1913 onwards. For professors who according to their CVs either obtained their doctoral degree abroad or do not have a $\mathrm{PhD}$, we used the year of their first publication as a proxy for the beginning of their academic career. If professors had very common surnames like "Müller" or "Fischer" and also common first names, we preferred to drop these from our data since publication and/or patent data could not be uniquely identified for them.
} 
about 120 thousand Euros on average or about $22 \%$ of their total budget. Research units spend on average $42 \%$ of their time on basic research. The share is higher at universities $(57 \%)$ and considerably lower at Polytechnics (4\%). At technical universities the average share of applied research is $62 \%$. The relative focus on applied research naturally differs between fields of research. Electrical Engineering, Mechanical Engineering and other Engineering report high shares of $79 \%, 77 \%$ and $74 \%$, respectively. Research units in Chemistry and Physics spend about $61 \%$ and $69 \%$ of their time of basic research, while and Mathematicians and Computer Scientists and Biologists have basic research shares of $56 \%$ and $50 \%$, respectively. Professors in the sample published on average eleven items in the period 19941999 and occurred 1.4 times as inventor on a patent application. The numbers vary by research field and type of institution (see Table A.2). The size of the institutions differs in student numbers ranging from 1,451 to nearly 60 thousand students. The share of scientists of a unit's total staff is $73 \%$ on average. The share is slightly lower at polytechnics $(68 \%)$ and technical universities (71\%). The professors have an average experience of about 22 years in academe. $73 \%$ of them had some form of contact to a TTO and only $3 \%$ of them are female.

Table 1: Descriptive Statistics (699 obs.)

\begin{tabular}{|c|c|c|c|c|c|}
\hline Variable & Description & Mean & Std. Dev & Min & Max \\
\hline \multicolumn{6}{|l|}{ Grant-based funding } \\
\hline$I_{N D F U N D_{t}}$ & $\mathrm{~T} €$ & 96.43 & 219.90 & 0 & $2,129.53$ \\
\hline$I N D S H A R E_{t}$ & $\%$ of total budget & 8.61 & 13.48 & 0 & 100 \\
\hline$G O V F U N D_{t}$ & $\mathrm{~T} €$ & 118.31 & 244.44 & 0 & $1,844.53$ \\
\hline GOVSHARE $E_{t}$ & $\%$ of total budget & 21.71 & 20.22 & 0 & 100 \\
\hline \multicolumn{6}{|l|}{ Research orientation } \\
\hline$\overline{B A S I C \_S H A R E}$ & $\% / 100$ & 0.42 & 0.34 & 0 & 1 \\
\hline APPLIED_SHARE & $\% / 100$ & 0.58 & 0.34 & 0 & 1 \\
\hline \multicolumn{6}{|l|}{ Controls } \\
\hline$\overline{P U B S_{t-6 \text { to } t}}$ & publication count & 11.08 & 20.51 & 0 & 243 \\
\hline PUBCITS $_{t-6 \text { to } t}$ & citation count & 228.16 & 571.22 & 0 & 5,907 \\
\hline$P A T S_{t-6 \text { to } t}$ & patent count & 1.41 & 3.48 & 0 & 32 \\
\hline PATCITS $_{\text {t- } 6 \text { to } t}$ & citation count & 20.25 & 126.61 & 0 & 2,634 \\
\hline UNI_SIZE & student count & $17,789.40$ & $11,817.00$ & 1,451 & 59,599 \\
\hline SCI_STAFF & $\%$ if total staff & 73.24 & 17.13 & 6.66 & 100 \\
\hline$E X \bar{P} E R$ & years since $\mathrm{PhD}$ & 21.64 & 8.68 & 1 & 43 \\
\hline TTO & dummy & 0.73 & 0.44 & 0 & 1 \\
\hline FEMALE & dummy & 0.03 & 0.18 & 0 & 1 \\
\hline
\end{tabular}

Note: Pair-wise correlations between the variables are presented in Table A.1. Institution-type dummies and field dummies not presented (see Table A.2 in the Appendix). Note also that the time period for the controls for past scientific includes $t$ as articles published in $t$ have usually been written in the years up to $t$, thus reflecting research outcomes of the period $t-l$ or earlier. The same applies to patents applied for in $t$.

\section{ECONOMETRIC ANALYSIS AND RESULTS}


The research unit's amount of industry funding (INDFUND, and the share of this funding as \% of total budget INDSHARE) as well the amount and share of public grants (GOVFUND, GOVSHARE) are the dependent variables of interest in the following econometric analysis. Not all professors in the sample attracted third-party funds, however. More than $1 / 3$ of the professors had no funding from the private sector, that is, INDFUND is left censored. $22 \%$ of the observations for GOVFUND are also censored. In $13 \%$ of these cases the research unit was financed by core budget only. Hence, Tobit models are being estimated to account for this bias. The models to be estimated can be written as

$$
Y^{*}=X^{\prime} \beta+\varepsilon
$$

where the unobserved latent variable $Y^{*}$ is equal to INDSHARE and GOVSHARE in the first set of models and to the logarithm of INDFUND* and GOVFUND* $(+1)$, respectively, in the second set of specifications. The observed dependent variable is equal to

$$
Y=\left\{\begin{array}{l}
Y^{*} \text { if } X^{\prime} \beta+\varepsilon>0 \\
0 \text { otherwise }
\end{array} .\right.
$$

$X$ represents the matrix of regressors, $\beta$ the parameters to be estimated, and $\varepsilon$ the random error term.

\section{The impact of research orientation on acquisition of research grants}

The main hypothesis concerns the effects of a unit's research orientation (BASIC or APPLIED) on third-party funding. Remember that in order to avoid collinearity between the regressors BASIC_SHARE and APPLIED_SHARE (as they add up to 1), the individual shares had been multiplied with the number of scientific staff. This transformation led to a slight shift in interpretation of the variable from 'share of effort devoted to basic or applied research' to 'staff working on basic or applied research'. To test for complementarity between the two, an interaction term $B A S I C^{*} A P P L I E D$ is added to the model. The main equation of interest can thus be specified as

$$
E\left(\ln Y^{*}\right)=\beta_{0}+\beta_{1} B A S I C+\beta_{2} A P P L I E D+\beta_{3}\left(B A S I C^{*} A P P L I E D\right)+\beta_{4} E X P E R+\beta_{5}(E X P E R)^{2}
$$

$$
+\beta_{6} T T O+\beta_{7} \ln \left(U N I \_S I Z E\right)+\beta_{8} \ln \left(U N I_{-} S I Z E\right)^{2}+\sum_{k=9}^{15} \beta_{k} F_{I E L D}+\sum_{s=16}^{18} \beta_{s} I N S T Y P E_{s}
$$


where $F I E L D_{k}$ refer to the seven research areas and INSTYPE refers to the three different type of institutions (UNI, TU, POLYTECH).

Subsequent to this core specification, we will add the research track record of unit's heads (PUBS and PATS), information on the lab's skill composition (TECHS, POSTDOCS, PROFS) and gender (FEMALE). Due to the skewed distributions of patents and publications, the logs of these variables are included. For those with zero patents or publications, i.e. if the log is not defined, a dummy variable is included to capture the "quasi-missing" value (NO_PUB_DUM, NO_PAT_DUM).

The standard Tobit model requires the assumption of homoscedasticity; otherwise the estimates are inconsistent (cf. Greene, 2000). Tests on heteroscedasticity (Wald tests and LR Tests) using a heteroscedastic specification of the Tobit model in which the homoscedastic standard error $\sigma$ was replaced with $\sigma_{i}=\sigma \exp \left(Z^{\prime} \alpha\right)$ in the likelihood function find indeed evidence of heteroscedasticity. Consequently, regional dummies, one for each of the 16 German states, field and institution type dummies were used to model group-wise multiplicative heteroscedasticity. The presented estimation results are thus obtained from heteroscedastic-consistent estimations.

Table 2 presents the regression results of six specifications: The first is the core specification without the interaction term BASIC*APPLIED, the second model introduces this interaction term. Column three presents the results from the extended model including additional controls for past research output and gender. Columns four to six present the results of the Tobit models on GOVSHARE instead of INDSHARE.

The results show that basic research reduces the share of funding from industry, whereas applied research has a significantly positive effect in all three specifications. The inclusion of the interaction term reveals that research units that do both basic as well as applied research have a larger share of industry grants compared to more specialized units. On the contrary, the models on GOVSHARE show a negative sign for the interaction term which indicates a substitutive relationship between basic and applied research for the attraction of public grants. That is, higher values for both APPLIED and BASIC individually increases GOVSHARE. In other words, specialized research units show a higher share of each type of competitive research funding. The control variables show the expected effects. Having contact to a TTO increases industry funding, but has no effect on public grants. The share of industry grants is higher at larger institutions up to a size of about 14,000 students, but is decreasing with the number of 
students at larger institutions. Moreover, having no past patent experience reduces the share of industry grants. The coefficient of the variable capturing past publications has the expected positive sign for public grants pointing to the importance of scientific achievements for raising such funds. Past patent application were not found to be significant for the share or amount of public grants.

Turning to the results on the total amount of grants (GOVFUND) instead of the share of total budget, the key insights are confirmed. However, most control variables are now insignificant (Table 3). The estimated coefficients describe the marginal effects of the regressors on the investment propensity $\mathrm{Y}^{*}$, such that

$$
\frac{\partial E\left[Y_{i}^{*} \mid x_{i}^{\prime}\right]}{\partial x_{i k}}=\beta_{k} .
$$

(see e.g. Greene, 2000: 908-910). Since the dependent variable in this model is specified in logarithms, a unit change in our main variables of interest, i.e. BASIC and APPLIED, can be interpreted as a percentage change in funding. Recall that a unit change in BASIC or APPLIED means that an additional person works in the lab on applied or basic research. For instance in the third specification of Table 3, if APPLIED changes by one unit, industry funding (in terms of the latent index $\mathrm{Y}^{*}$ ) increases by $8.1 \%$ and public grants by $10.8 \%$. If BASIC changes by one unit, government grants (column 6) increase by about $10 \%$, all else constant.

The marginal effect could alternatively be computed based on $\mathrm{Y}$ instead of $\mathrm{Y}^{*}$ as

$$
\frac{\partial E\left[Y_{i} \mid x_{i}^{\prime}\right]}{\partial x_{i k}}=\beta_{k} \cdot \Phi\left(\frac{x_{i}^{\prime} \beta}{\sigma}\right) .
$$

In this case, INDFUND increases by $7.4 \%$ if APPLIED changes by one unit, on average. Public grants would increase by $6.7 \%$ in response to an additional person working on basic research, and by $7.2 \%$ for an additional applied researcher.

To graphically illustrate the complementary relationship between basic and applied research for attracting funds from industry, Figure 1 depicts the expected values for the amount of industry funding for different values of BASIC and APPLIED, respectively. Graph 1(a) shows that INDFUND decreases as BASIC increases, but that the decrease occurs at a lower rate and at a higher level for larger values of APPLIED (at $0,25^{\text {th }}, 50^{\text {th }}$ and $75^{\text {th }}$ percentiles of the distribution of APPLIED). Correspondingly, $\mathrm{E}(I N D F U N D)$ is not only higher for higher values of $B A S I C$, but also increases at higher rates (Graph 1b). 
The substitutive relationship of basic and applied research is illustrated in Graphs 2 (a) and (b). The expected value of public grants increases with the share of workforce dedicated to either basic (a) or applied (b) research. The increase, however, occurs at higher rates for lower levels of the opposed research focus up from a point in which this focus gets stronger than the other.

Table 2: Tobit regressions on source of funding as share of total budget (669 obs.)

\begin{tabular}{|c|c|c|c|c|c|c|}
\hline \multirow{2}{*}{$\begin{array}{l}\text { Variable } \\
B A S I C\end{array}$} & \multicolumn{3}{|c|}{ Tobit Models on INDSHARE } & \multicolumn{3}{|c|}{ Tobit Models on GOVSHARE } \\
\hline & $-0.153 *$ & $-0.323 * *$ & $-0.320 * *$ & $0.252 * *$ & $0.538 * * *$ & $0.454 * * *$ \\
\hline & $(0.085)$ & $(0.132)$ & $(0.137)$ & $(0.120)$ & $(0.169)$ & $(0.173)$ \\
\hline \multirow[t]{2}{*}{ APPLIED } & $0.321 * * *$ & $0.229 * *$ & $0.196 * * *$ & $0.344 * * *$ & $0.516^{* * *}$ & $0.519 * * *$ \\
\hline & $(0.082)$ & $(0.090)$ & $(0.085)$ & $(0.125)$ & $(0.160)$ & $(0.172)$ \\
\hline \multirow[t]{2}{*}{$B A S I C * A P P L I E D$} & & $0.013 * *$ & $0.013 * *$ & & $-0.019 * * *$ & $-0.017 * * *$ \\
\hline & & $(0.006)$ & $(0.006)$ & & $(0.006)$ & $(0.006)$ \\
\hline \multirow[t]{2}{*}{ EXPER } & 0.275 & 0.296 & 0.287 & $0.854 *$ & 0.783 & 0.835 \\
\hline & $(0.333)$ & $(0.340)$ & $(0.305)$ & $(0.512)$ & $(0.512)$ & $(0.521)$ \\
\hline \multirow[t]{2}{*}{$E X P E R^{2}$} & -0.010 & -0.010 & -0.009 & -0.018 & -0.017 & -0.017 \\
\hline & $(0.007)$ & $(0.008)$ & $(0.007)$ & $(0.012)$ & $(0.012)$ & $(0.012)$ \\
\hline \multirow[t]{2}{*}{ TTO } & $3.927 * * *$ & $4.136^{* * *}$ & $3.404 * *$ & 3.032 & 2.689 & 2.461 \\
\hline & $(1.516)$ & $(1.542)$ & $(1.498)$ & $(2.022)$ & $(2.032)$ & $(2.055)$ \\
\hline \multirow[t]{2}{*}{$\ln \left(U N I \_S I Z E\right)$} & $93.573 * * *$ & $91.531 * * *$ & $88.936^{* * *}$ & 16.759 & 24.552 & 22.597 \\
\hline & $(31.572)$ & $(31.084)$ & $(31.477)$ & $(35.785)$ & $(37.710)$ & $(37.579)$ \\
\hline \multirow[t]{2}{*}{$\ln \left(U N I \_S I Z E^{2}\right)$} & $-4.903 * * *$ & $-4.771 * * *$ & $-4.612 * * *$ & -0.686 & -1.139 & -1.007 \\
\hline & $(1.653)$ & $(1.627)$ & (1.649) & $(1.879)$ & $(1.975)$ & $(1.970)$ \\
\hline \multirow[t]{2}{*}{$\ln (P U B S)$} & & & -0.729 & & & $1.928 * *$ \\
\hline & & & $(0.712)$ & & & $(0.924)$ \\
\hline \multirow[t]{2}{*}{$\ln (P A T S)$} & & & 0.914 & & & 1.862 \\
\hline & & & $(1.120)$ & & & $(1.676)$ \\
\hline \multirow[t]{2}{*}{$N O \_P U B \_D U M$} & & & -1.538 & & & -0.281 \\
\hline & & & $(1.884)$ & & & $(2.863)$ \\
\hline \multirow[t]{2}{*}{$N O \_P A T \_D U M$} & & & $-3.450 * *$ & & & 2.997 \\
\hline & & & $(1.721)$ & & & $(2.307)$ \\
\hline \multirow[t]{2}{*}{ FEMALE } & & & 0.076 & & & 2.209 \\
\hline & & & $(2.189)$ & & & $(4.838)$ \\
\hline $\begin{array}{l}\text { Joint significance of } \\
\text { institution dummies } \chi^{2}(2)\end{array}$ & $29.66 * * *$ & $26.89 * * *$ & $21.60 * * *$ & $25.97 * * *$ & $26.41 * * *$ & $24.96 * * *$ \\
\hline $\begin{array}{l}\text { Joint significance field } \\
\text { dummies } \chi^{2}(6)\end{array}$ & $42.16^{* * *}$ & $41.27 * * *$ & $31.68 * * *$ & $32.09 * * *$ & $33.15 * * *$ & $30.35 * * *$ \\
\hline $\begin{array}{l}\text { Joint significance Länder } \\
\text { dummies } \chi^{2}(15)\end{array}$ & $88.38 * * *$ & $84.37 * * *$ & $99.21 * * *$ & $51.94 * * *$ & $48.85^{* *}$ & $51.83 * * *$ \\
\hline Log-Likelihood & $-1,855.67$ & $-1,853.78$ & $-1,851.48$ & $-2,410.06$ & $-2,406.32$ & $-2,402.02$ \\
\hline \# censored obs. & & 260 & & & 147 & \\
\hline
\end{tabular}


Figure 1: Expected Values of the amount of industry grants

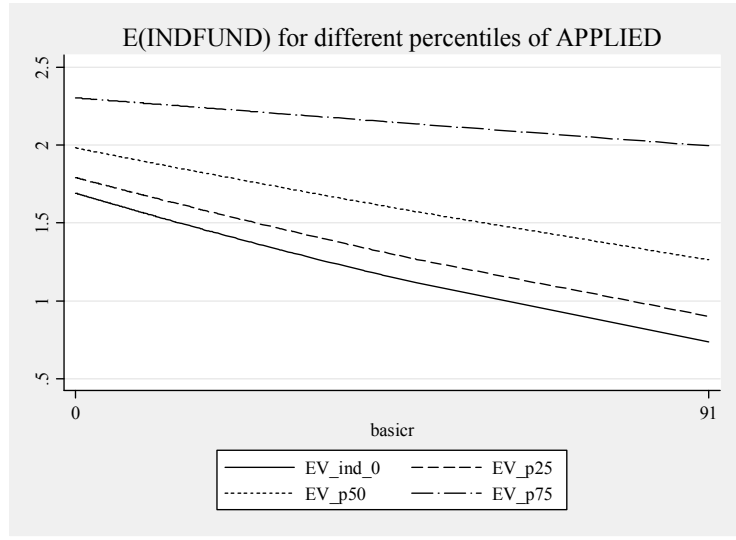

Graph 1(a)

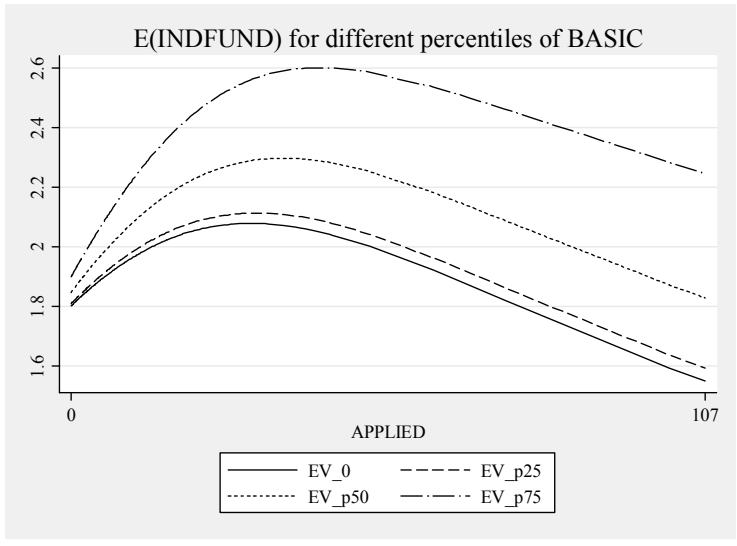

Graph 1(b)

Figure 2: Expected Values of the amount of public grants

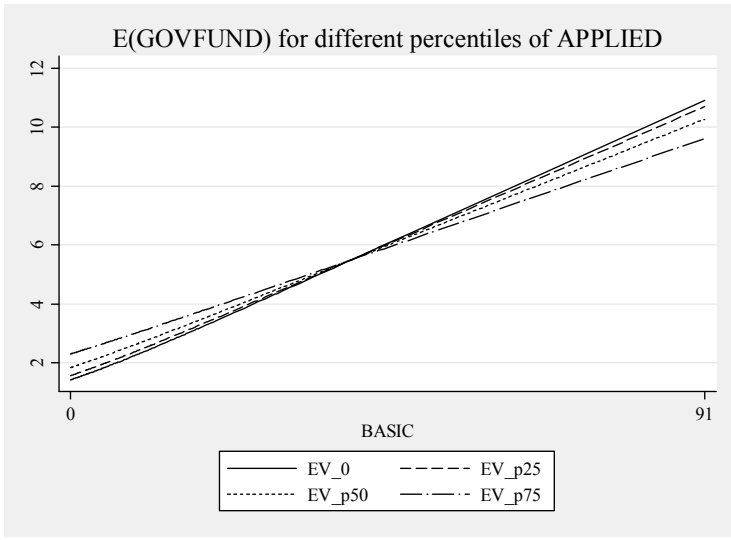

Graph 2(a)

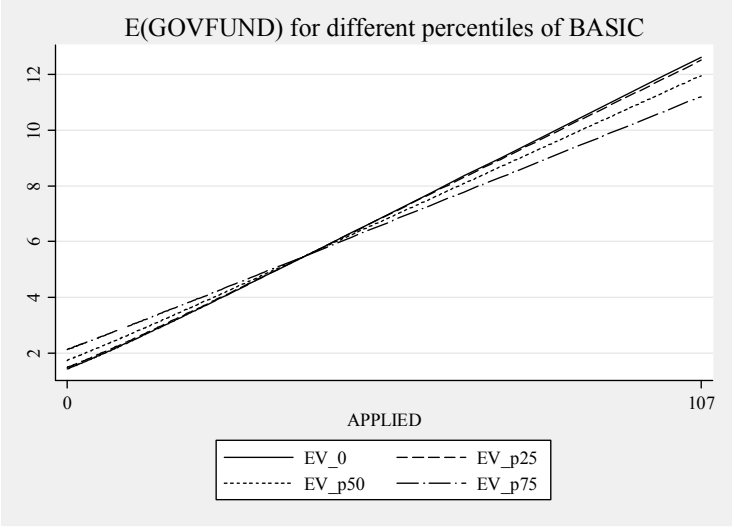

Graph 2(b) 
Table 3: Tobit regressions on source of funding ( $669 \mathrm{obs}$.

\begin{tabular}{|c|c|c|c|c|c|c|}
\hline \multirow{2}{*}{$\begin{array}{l}\text { Variable } \\
B A S I C\end{array}$} & \multicolumn{3}{|c|}{ Tobit Models on $\ln (I N D F U N D+1)$} & \multicolumn{3}{|c|}{ Tobit Models on $\ln (G O V F U N D+1)$} \\
\hline & 0.007 & -0.025 & -0.027 & $0.063 * * *$ & $0.105 * * *$ & $0.098 * * *$ \\
\hline & $(0.015)$ & $(0.027)$ & $(0.027)$ & $(0.013)$ & $(0.016)$ & $(0.015)$ \\
\hline \multirow[t]{2}{*}{ APPLIED } & $0.101 * * *$ & $0.086^{* * *}$ & $0.081 * * *$ & $0.083 * * *$ & $0.107 * * *$ & $0.108 * * *$ \\
\hline & $(0.018)$ & $(0.020)$ & $(0.020)$ & $(0.009)$ & $(0.013)$ & $(0.013)$ \\
\hline \multirow[t]{2}{*}{$B A S I C * A P P L I E D$} & & $0.002 *$ & $0.002 * *$ & & $-0.003 * * *$ & $-0.002 * * *$ \\
\hline & & $(0.001)$ & $(0.001)$ & & $(0.001)$ & $(0.001)$ \\
\hline \multirow[t]{2}{*}{ EXPER } & 0.036 & 0.042 & 0.041 & $0.080 *$ & 0.063 & 0.074 \\
\hline & $(0.070)$ & $(0.072)$ & $(0.071)$ & $(0.046)$ & $(0.044)$ & $(0.045)$ \\
\hline \multirow[t]{2}{*}{$E X P E R^{2}$} & -0.001 & -0.001 & -0.001 & -0.002 & -0.001 & -0.001 \\
\hline & $(0.002)$ & $(0.002)$ & $(0.002)$ & $(0.001)$ & $(0.001)$ & $(0.001)$ \\
\hline \multirow[t]{2}{*}{ TTO } & $1.134 * * *$ & $1.174 * * *$ & $1.016 * * *$ & $0.545 * * *$ & $0.468 * * *$ & $0.457 * * *$ \\
\hline & $(0.312)$ & $(0.317)$ & $(0.323)$ & $(0.175)$ & $(0.169)$ & $(0.170)$ \\
\hline \multirow[t]{2}{*}{$\ln \left(U N I \_S I Z E\right)$} & 7.347 & 6.639 & 5.575 & 1.714 & 2.816 & 2.170 \\
\hline & $(5.289)$ & $(5.256)$ & $(5.246)$ & $(3.454)$ & $(3.597)$ & $(3.672)$ \\
\hline \multirow[t]{2}{*}{$\ln \left(U N I \_S I Z E^{2}\right)$} & -0.367 & -0.325 & -0.264 & -0.067 & -0.129 & -0.094 \\
\hline & $(0.279)$ & $(0.278)$ & $(0.278)$ & $(0.180)$ & $(0.187)$ & $(0.191)$ \\
\hline \multirow[t]{2}{*}{$\ln (P U B S)$} & & & -0.058 & & & $0.248 *$ \\
\hline & & & $(0.131)$ & & & $(0.133)$ \\
\hline \multirow[t]{2}{*}{$\ln (P A T S)$} & & & 0.126 & & & 0.096 \\
\hline & & & $(0.202)$ & & & $(0.075)$ \\
\hline \multirow[t]{2}{*}{$N O_{-} P U B_{-} D U M$} & & & -0.310 & & & -0.302 \\
\hline & & & $(0.379)$ & & & $(0.256)$ \\
\hline \multirow[t]{2}{*}{$N O \_P A T \_D U M$} & & & $-0.692 * *$ & & & 0.327 \\
\hline & & & $(0.311)$ & & & $(0.211)$ \\
\hline \multirow[t]{2}{*}{ FEMALE } & & & 0.141 & & & 0.164 \\
\hline & & & $(0.672)$ & & & $(0.512)$ \\
\hline $\begin{array}{l}\text { Joint significance of } \\
\text { institution dummies } \chi^{2}(2)\end{array}$ & $17.17 * * *$ & $17.19 * * *$ & $15.52 * * *$ & $36.18 * * *$ & $75.89 * * *$ & $79.39 * * *$ \\
\hline $\begin{array}{l}\text { Joint significance field } \\
\text { dummies } \chi^{2}(6)\end{array}$ & $59.18 * * *$ & $53.72 * * *$ & $43.59 * * *$ & $75.50 * * *$ & $38.06^{* * *}$ & $36.13 * * *$ \\
\hline $\begin{array}{l}\text { Joint significance Länder } \\
\text { dummies } \chi^{2}(15)\end{array}$ & $52.41 * * *$ & $50.34 * *$ & $48.61 * *$ & $71.77 * * *$ & $77.21 * * *$ & $74.19 * * *$ \\
\hline Log-Likelihood & $-1,184.01$ & $-1,182.23$ & $-1,179.05$ & $-1,162.25$ & $-1,152.80$ & $-1,147.28$ \\
\hline \# censored obs. & & 260 & & & 147 & \\
\hline
\end{tabular}

\section{ROBUSTNESS TESTS}

As a robustness check, all models have been estimated accounting for quality weighted measures of past research performance. The results confirm previous findings for the main variables of interest. The total number of citations to past publications (in the pre sample period 1994-1999) is positive and significant in the GOVFUND equation, but insignificant in for INDFUND. The same is true for citations per publication. It is noteworthy that the marginal effects are larger for the quality-weighted measures for scientific output (compare Tables 2 and 4). Thus, the quality of scientific output seems not only to be important, but also to be 
more important for public grants than for industry grants. As before, professors without patents receive a significantly lower share of their funding from industry. All other measures for scientific excellence even if weighted by citations, however, appear not to affect the share of industry funding as long as we control for research orientation.

As a second check we ran all models with the BASIC and APPLIED shares being multiplied with the total number of staff instead of scientific staff. The results remain robust to this variation.

Table 4: Tobit regressions on source of funding (INDSHARE, GOVSHARE) with qualityweighted publications and patents (669 obs)

\begin{tabular}{|c|c|c|c|c|}
\hline Variable & $\begin{array}{c}\text { INDSHARE } \\
\text { with citations } \\
\text { per PUB / PAT }\end{array}$ & $\begin{array}{l}\text { INDSHARE } \\
\text { with citation } \\
\text { count }\end{array}$ & $\begin{array}{c}\text { GOVSHARE } \\
\text { with citations } \\
\text { per PUB / PAT }\end{array}$ & $\begin{array}{c}\text { GOVSHARE } \\
\text { with citation } \\
\text { count }\end{array}$ \\
\hline \multirow[t]{2}{*}{ BASIC } & $-0.315^{* *}$ & $-0.315^{* *}$ & $0.509^{* * *}$ & $0.437 * * *$ \\
\hline & $(0.135)$ & $(0.137)$ & $(0.152)$ & $(0.160)$ \\
\hline \multirow[t]{2}{*}{ APPLIED } & $0.224 * * *$ & $0.220 * * *$ & $0.515 * * *$ & $0.518 * * *$ \\
\hline & $(0.083)$ & $(0.085)$ & $(0.160)$ & $(0.170)$ \\
\hline \multirow[t]{2}{*}{$B A S I C * A P P L I E D$} & $0.012 *$ & $0.012 * *$ & $-0.019 * * *$ & $-0.017 * * *$ \\
\hline & $(0.006)$ & $(0.006)$ & $(0.006)$ & $(0.006)$ \\
\hline \multirow[t]{2}{*}{ EXPER } & 0.139 & 0.145 & 0.830 & $0.871 *$ \\
\hline & $(0.335)$ & $(0.344)$ & $(0.513)$ & $(0.521)$ \\
\hline \multirow[t]{2}{*}{$E X P E R^{2}$} & -0.006 & -0.006 & -0.017 & -0.018 \\
\hline & $(0.007)$ & $(0.008)$ & $(0.012)$ & $(0.012)$ \\
\hline \multirow[t]{2}{*}{ TTO } & $3.694 * *$ & $3.744 * *$ & 2.627 & 2.767 \\
\hline & $(1.532)$ & $(1.534)$ & $(2.088)$ & $(2.089)$ \\
\hline \multirow[t]{2}{*}{$\ln \left(U N I \_S I Z E\right)$} & $91.173 * * *$ & $92.554 * * *$ & 33.351 & 28.714 \\
\hline & $(31.11)$ & $(31.213)$ & $38.018)$ & $(37.765)$ \\
\hline \multirow[t]{2}{*}{$\ln \left(U N I S S I Z E^{2}\right)$} & $-4.742 * * *$ & $-4.812 * * *$ & -1.603 & -1.336 \\
\hline & (1.629) & $(1.634)$ & (1.988) & $(1.978)$ \\
\hline \multirow[t]{2}{*}{ CIT_PUB } & & 0.012 & & $2.053 * * *$ \\
\hline & & $(0.490)$ & & $(0.704)$ \\
\hline \multirow[t]{2}{*}{ CIT_PAT } & & -0.618 & & -0.142 \\
\hline & & $(0.615)$ & & $(0.934)$ \\
\hline \multirow[t]{2}{*}{$C I T \_p e r \_P U B$} & 0.274 & & $2.889 * *$ & \\
\hline & $(0.757)$ & & $(1.140)$ & \\
\hline \multirow[t]{2}{*}{ CIT_per_PAT } & -1.175 & & -1.576 & \\
\hline & $(0.658)$ & & $(1.284)$ & \\
\hline \multirow[t]{2}{*}{ NO_PUB_DUM } & 1.228 & 0.710 & 3.291 & 4.998 \\
\hline & $(2.192)$ & $(2.374)$ & $(3.123)$ & $(3.397)$ \\
\hline \multirow[t]{2}{*}{$N O \_P A T \_D U M$} & $-5.271 * * *$ & $-5.054 * *$ & -0.426 & 1.954 \\
\hline & $(1.674)$ & $(2.130)$ & $(3.169)$ & $(3.342)$ \\
\hline \multirow[t]{2}{*}{ GENDER } & 0.405 & 0.469 & 2.144 & 2.539 \\
\hline & $(2.029)$ & $(2.063)$ & $(4.875)$ & $(4.811)$ \\
\hline Joint sig. inst. dum. $\chi 2(2)$ & $23.76^{* * *}$ & $22.72 * * *$ & $25.47 * * *$ & $24.57 * * *$ \\
\hline Joint sig. field dum. $\chi^{2}(6)$ & $32.54 * * *$ & $32.75 * * *$ & $29.92 * * *$ & $30.08 * * *$ \\
\hline Joint sig. Länder dum. $\chi^{2}$ (15) & $107.40 * * *$ & $102.66^{* * *}$ & $49.05 * *$ & $52.03 * * *$ \\
\hline Log-Likelihood & $-1,853.23$ & $-1,854.14$ & $-2,400.21$ & $-2,399.60$ \\
\hline \# censored obs. & 260 & 260 & 147 & 147 \\
\hline
\end{tabular}




\section{CONCLUSIONS}

Given the increasing share of competitive grants - from public as well as private sector sources - supplementing universities core funding, the objective of this paper was to provide an analysis in the role of direction of faculty research in terms of basic versus applied research for attracting such grants. Although, we see that applied research indeed increases the share of industry funding of the research units' total budgets as well as the amount, the complementarity between basic and applied research for success in raising industry grants suggests that researchers who provide basic scientific input as well as competencies on the applicability of such are most attractive targets for funding from the business sector. Thus, firms appear to seek access to basic science that is not feasible or not profitable to built-up inhouse, but also rely on the scientists' ability to translate it into applicable technology. This points to a trade-off faced by the sponsoring firm between the advantage of sourcing basic science from universities and the costs of building absorptive capacities in-house to effectively use this knowledge. Collaborating with university research labs that are able to conduct both basic as well as applied research may reduce these costs, and hence, alleviate the trade-off.

With respect to public grants the results suggest that public funding-authorities prize specialization. Research units with either a strong focus on either basic or on applied research raise significantly more grants than others. This is in line with previous findings. Applicationoriented research, for instance, has been shown to benefit from supra-national funding programs such as the EU-wide "Framework Programme for Research and Development". In Germany also so-called "direct project funding" by the Federal Government has been to an increasing extent directed at promoting industry-science consortia that aim at research that is are more likely to be applied in nature. Grant programs by the German Research Foundation (DFG), on the other hand, may support rather basic research agendas as they attract applicants with particular high scientific excellence if measured in publications and citations (Grimpe 2010). Moreover, the result that private sector and public grants are subject to different criteria with respect to research orientation suggests that industry grants offer a additional source of competitive funding for research units that may not be willing or not be able to raise other types of grants.

However, the results ought to be interpreted with the study's limitations in mind. Given the available data it was not possible to account for the dynamics between ex-ante research orientation that shapes the attractiveness for receiving industry funding and the incentives to 
adopt a certain orientation to become more attractive for funding and the effects of funding on future research orientation. Panel data on a set of professors and their research unit would be desirable for such an exercise. Thus, it is important to stress that this study identified multivariate correlations and not necessarily a causal link. Further analysis would, moreover, not only benefit from distinguishing between types of public grants, but also from studying the providers of industry grants in greater detail. As results for the U.S by Cohen et al. (2002) suggest, it is very likely that the observed effects differ substantially between industries, firms of different sizes and different stages of maturity. Further research should also take into account the impact of 'outside-factors' such as government-subsidized cost sharing in publicprivate partnerships and their effects of industry-funded university research that may also cross-impact the researchers attention to other public funding schemes. 


\section{REFERENCES}

Acs, Z., Audretsch, D. and M. Feldman (1992), Real Effects of Academic Research: Comment, American Economic Review 82, 363-367.

Auranen, O. and M. Nieminen (2010), University Research Funding and Publication Performance - An International Comparison, Research Policy 39, 822-834.

Beise, M. and H. Stahl (1999), Public Research and Industrial Innovations in Germany, Research Policy 28, 397-422.

Bozeman, B. and M. Gaughan (2007), Impacts of Grants and Contracts on Academic Researchers' Interactions with Industry, Research Policy 36, 694-707.

Broström, A. (2011), Firms Rationales for Intersection with Research Universities and the Principles for Public Co-Funding, Journal of Technology Transfer, forthcoming.

Cassiman, B., Veugelers, R., and M.P. Zuniga (2008), In Search of Performance Effects of (In)direct Industry Science Links, Industrial and Corporate Change 17 (4), 611-646.

Cassiman, B., Veugelers, R., and M.P. Zuniga (2010), Diversity of Science Linkages and Innovation Performance: Some Empirical Evidence from Flemish Firms, Economics: The Open-Access, Open-Assessment E-Journal, vol. 3.

Cockburn, I. and R. Henderson (1998), Absorptive Capacity, Coauthoring Behavior, and the Organization of Research in Drug Discovery, Journal of Industrial Economics 46, 157 182.

Cockburn, I., R. Henderson and S. Stern (1999), Balancing Incentives: The Tension between Basic and Applied Research, NBER Working Paper No. W6882.

Cohen, W., R. Nelson and J. Walsh (2002), Links and impacts: the influence of public research on industrial R\&D, Management Science 48, 1-23.

Crespi, G.A., Geuna, A. and L. Nesta (2007), The Mobility of University Inventors in Europe, The Journal of Technology Transfer 32(3), 195-215.

Czarnitzki, D. and C. Rammer (2003), Technology transfer via the Internet: A way to link public science and enterprises?, Journal of Technology Transfer 28(2), 131-147.

Czarnitzki, D., K. Hussinger and C. Schneider (2008), Commercializing Academic Research: The Quality of Faculty Patenting, ZEW Discussion Paper No. 08-069, Mannheim.

Czarnitzki, D., K. Hussinger und C. Schneider (2009), Why Challenge the Ivory Tower? New Evidence on the Basicness of Academic Patents, Kyklos 62(4), 488-499.

Dasgupta, P. and P. David (1994), Towards a New Economics of Science, Research Policy 3, 487-521.

Feldman, M.P. and M.R. Kelley (2006), The ex ante assessment of knowledge spillovers: Government R\&D policy, economic incentives and private firm behavior, Research Policy 35, 1509-1521.

Fleming, L., and O. Sorenson (2004), Science as a Map in Technological Search, Strategic Management Journal 25, 909-928.

Gambardella, A. (1992), Competitive Advantages From In-house Scientific Research: The US Pharmaceutical Industry in the 1980s, Research Policy 21(5), 391-407. 
Geuna, A. (2001), The Changing Rationale for European University Research Funding: Are There Negative Unintended Consequences?, Journal of Economic Issues 35, 607-632.

Geuna A. and Nesta L., (2006), University Patenting and its Effects on Academic Research: the Emerging European Evidence, Research Policy 35, 790-807.

Greene, W.H. (2000), Econometric Analysis, $4^{\text {th }}$ edition, Prentice-Hall, New Jersey.

Grimpe. C. (2010), Scientific Excellence and Extramural Research Grants: Beggars Can't Be Choosers?, ZEW Discussion Paper No. 10-031, Mannheim.

Grimpe. C. and H. Fier (2009), Informal University Technology Transfer: A Comparison Between the United States and Germany, ZEW Discussion Paper No. 09-033, Mannheim.

Gulbrandsen, M. and J.C. Smeby (2005), Industry Funding and University Professors' Research Performance, Research Policy 34, 932 - 950.

Hall, B.H., Link, A.N. and J.T. Scott (2003), Universities as Research Partners, Journal of Economic Studies 85, 485-491.

Hall, B.H., Link, A.N. and J.T. Scott (2001a), Barriers Inhibiting Industry from Partnering with Universities: Evidence from the Advanced Technology Program, Journal of Technology Transfer 26, 87-98.

Hall, B.H., Jaffe, A. and M. Trajtenberg (2001), The NBER Patent Citations Data File: Lessons, Insights, and Methodological Tools, NBER Working Paper No. 8498.

Henderson, R., Jaffe, A. and M. Trajtenberg, (1998), Universities as a Source of Commercial Technology: a Detailed Analysis of University Patenting, 1965-1988, Review of Economics and Statistics 80(1), 119-127.

Hottenrott, H. und S. Thorwarth (2010), Industry Funding of University Research and Scientific Productivity, ZEW Discussion Paper No. 10-105, Mannheim.

Jacob, B. and L. Lefgren (2007), The Impact of Research Grant Funding on Scientific Productivity, NBER Working Paper No. 13519.

Jaffe, A. (1989), Real Effects of Academic Research, American Economic Review 79, 957970.

Jensen, R. and M. Thursby (2001), Proofs and Propotypes for Sale: The Licensing of University Inventions, American Economic Review 19(1), 240-259.

Jensen, R., Thursby, J. and Thursby, M. (2003), The Disclosure and Licensing of University Inventions, International Journal of Industrial Organization 21, 1271-1300.

Jensen, R., Thursby, J. and M. Thursby (2010), University-Industry Spillovers, Government Funding, and Industrial Consulting, NBER Working Paper No. 15732, Cambridge, MA.

Levin, S. and P. Stephan (1991), Research Productivity Over the Life Cycle: Evidence for Academic Scientists, American Economic Review 81(1), 114-132.

Ljungberg, D. (2008), What Industry Funding and Academic Patents Tell Us About University-Industry Interaction: The Case of Sweden, DRUID-DIME Academy Winter 2008 Conference Proceedings, Aalborg (Denmark).

Mansfield, E. (1991), Academic Research and Industrial Innovation, Research Policy 20, 112 . 
Mansfield, E. (1995), Academic Research Underlying Industrial Innovations: Sources, Characteristics, and Financing, Review of Economics and Statistics 77, 55-65.

Mansfield, E. (1998), Academic Research and Industrial Innovation: an Update of Empirical Findings, Research Policy 26, 773-776.

Mansfield, E. and J.-Y. Lee (1996), The Modern University: Contributor to Industrial Innovation and Recipient of Industrial R\&D Support, Research Policy 25, 1047-1058.

Mowery, D.C. (1998), The Changing Structure of the US National Innovation System: Implications for International Conflict and Cooperation in R\&D Policy, Research Policy 27, 639-654.

Murray, F. (2002), Innovation as Co-evolution of Scientific and Technological Networks: Exploring Tissue Engineering, Research Policy 31, pp. 1389-1403.

Narin, F., Hamilton, K.S. and D. Olivastro (1997), The Increasing Linkage between U.S. Technology and Public Science, Research Policy 26, 317-330.

Nelson, R. (1986), Institutions Supporting Technical Advance in Industry, American Economic Review 76, 186-189.

OECD (2007), Science, Technology and Innovation Indicators in a Changing World Responding to Policy Needs, OECD Publishing: Paris.

OECD (2009), Business-funded R\&D in the higher education and government sectors, in: OECD Science, Technology and Industry Scoreboard 2009, OECD: Paris.

Thursby, J. and M. Thursby (2002), Who is Selling the Ivory Tower? The Sources of Growth in University Licensing, Management Science 48(1), 90 - 104.

Thursby, J. and M. Thursby (2004), Are Faculty Critical? Their Role in University-Industry Licensing, Contemporary Economic Policy 22(2), 162 - 178.

Thursby, J., Thursby, M. and S. Gupta-Mukherjee (2007), Are There Real Effects of Licensing on Academic Research? A life cycle view, Journal of Economic Behavior and Organization 63, 577-598.

Toole, A. (2007). The Impact of Public Basic Research on Industrial Innovation: Evidence from the Pharmaceutical Industry, Stanford University (SIEPR) Discussion Paper 0007.

Trajtenberg, M. (2001), Innovation in Israel 1968-97: A Comparative Analysis Using Patent Data, Research Policy 30, 363 - 389.

Trajtenberg, M., Henderson, R. and A. Jaffe (1997), University versus Corporate Patents: A Window on the Basicness of Invention, Economics of Innovation and New Technology 5(1), pp. 19-50.

Salter, A.J. and Martin, B.R. (2001), The economic benefits of publicly funded basic research: a critical review, Research Policy 30, 509-532.

Schmoch, U. and T. Schubert (2009) Sustainability of Incentives for Excellent Research, Fraunhofer Institute for Systems and Innovation Research Discussion Paper, Karlsruhe.

Sorenson, O. and L. Fleming (2004), Science and the Diffusion of Knowledge, Research Policy 33, 1615-1633.

Stern, S. (2004), Do Scientists Pay to Be Scientists?, Management Science 50(6), 835-853. 
Veugelers, R. and Cassiman, B. (2005), R\&D cooperation between firms and universities Some empirical evidence from Belgian manufacturing, International Journal of Industrial Organization 23, 355- 379.

Viner, N., Powell, P. and R. Green (2004), Institutionalized Biases in the Award of Research Grants: A preliminary Analysis Revisiting the Principle of Accumulative Advantage, Research Policy 33, 443-454.

Von Hippel, E. (1988), The Sources of Innovation, Oxford University Press: New York.

Von Ledebur, S., Buenstorf, G. and Hummel, M. (2009), University patenting in Germany before and after 2002: What role did the professors' privilege play?, Jena Economic Research Papers \# 2009-068.

Zucker, L.G. and M.R. Darby (1996), Star Scientists and Institutional Transformation: Patterns of Invention and Innovation in the Formation of the Biotechnology Industry, Proceedings of the National Academy of Sciences (USA) 93, 12709-12716.

Zucker, L.G., Darby, M.R. and J.S. Armstrong (2002), Commercializing Knowledge: University Science, Knowledge Capture, and Firm Performance in Biotechnology, Management Science 48(1), 149-170. 


\section{APPENDIX}

Table A.1: Cross-Correlations Matrix between Main Variables

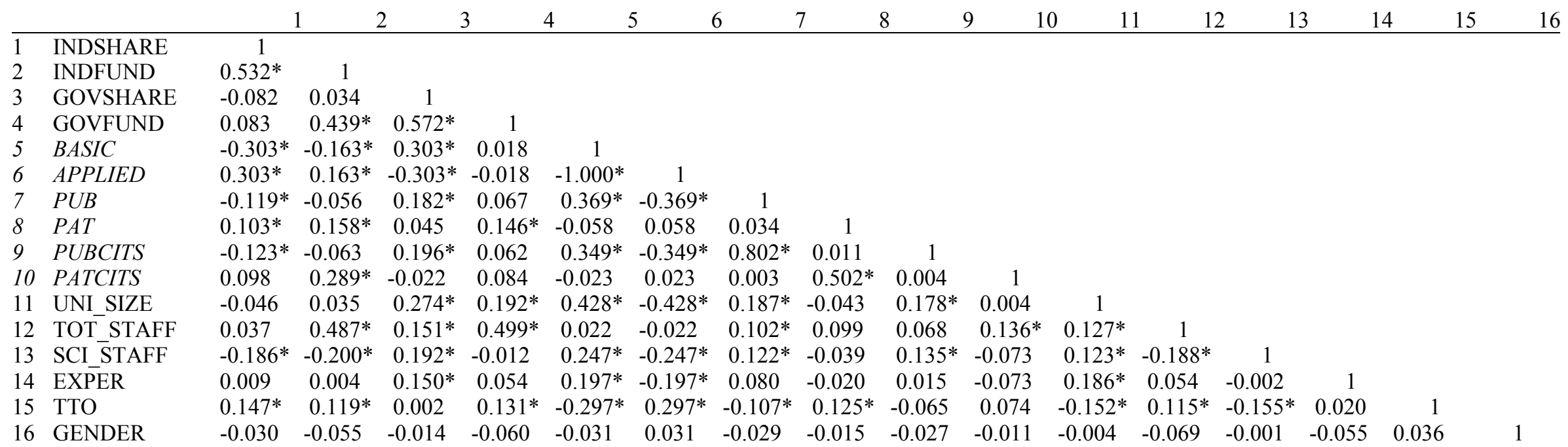

Note: * significant at $1 \%$ level

Table A.2: Grants, Research Orientation, and Research Performance by Research Fields and Institution Type (means)

\begin{tabular}{|c|c|c|c|c|c|c|c|c|c|}
\hline Field & \# obs & GOVSHARE & GOVFUND & INDSHARE & INDFUND & PUB & PUBCITS & PAT & PATCITS \\
\hline Physics & 101 & 32.03 & 149.72 & 4.29 & 45.68 & 22.90 & 627.76 & 1.13 & 17.61 \\
\hline $\begin{array}{l}\text { Mathematics and } \\
\text { Computer Science }\end{array}$ & 107 & 16.46 & 60.51 & 5.95 & 39.09 & 3.97 & 44.48 & 0.21 & 0.84 \\
\hline Chemistry & 95 & 22.10 & 82.22 & 6.06 & 68.05 & 27.52 & 513.24 & 1.80 & 23.24 \\
\hline Biology & 57 & 24.43 & 77.03 & 7.59 & 29.10 & 3.05 & 324.81 & 0.93 & 7.73 \\
\hline Electrical Engineering & 101 & 14.76 & 108.83 & 11.53 & 130.76 & 11.58 & 53.88 & 2.27 & 33.74 \\
\hline Mechanical Engineering & 108 & 21.68 & 174.52 & 14.00 & 205.35 & 3.93 & 27.06 & 1.84 & 40.39 \\
\hline Other Engineering & 100 & 22.00 & 155.84 & 10.05 & 123.51 & 6.73 & 88.38 & 1.57 & 12.59 \\
\hline Universities & 371 & 26.25 & 129.02 & 7.51 & 80.06 & 16.37 & 348.46 & 1.55 & 16.56 \\
\hline Technical Universities & 156 & 25.09 & 190.47 & 10.62 & 167.84 & 6.49 & 128.96 & 1.27 & 35.83 \\
\hline Polytechnics & 142 & 6.11 & 11.53 & 9.29 & 61.74 & 2.28 & 22.82 & 1.20 & 12.77 \\
\hline
\end{tabular}

